\title{
Performance and Carcass Characteristics of Broiler Chickens Fed Various Components of Candlenut Kernel
}

\author{
R. A. Rasid*, A. R. Baba, N. M. Yaakub, \& A. R. Milan \\ Livestock Programme, Faculty of Sustainable Agriculture, Universiti Malaysia Sabah \\ 90509 Sandakan, Sabah, Malaysia \\ *Corresponding author: rohaida.ar@ums.edu.my \\ (Received 18-12-2018; Revised 07-05-2019; Accepted 17-05-2019)
}

\begin{abstract}
One-hundred male broiler chickens (Cobb500) were assigned randomly in a completely randomized design (CRD) into four dietary treatment groups to determine the effects of various components (whole kernel, kernel oil, kernel defatted) of candlenut (Aleurites moluccana) kernel on growth performance, carcass yield, and proximate and fatty acid composition in meat during the grower-finisher stage. Each treatment consisted of 5 replicates with 5 birds for each replications. From 21 to 42 days of age, the birds were offered either one of the following dietary treatments namely; Basal diet containing no candlenut kernel (T1), Basal diet containing $2.5 \%$ whole candlenut kernel (T2), Basal diet containing 2.5\% candlenut kernel oil (T3), and Basal diet containing $2.5 \%$ candlenut kernel defatted (T4). The significant difference was determined when the probability level was $p<0.05$. Birds fed the experimental diets showed no significant difference on growth performance, carcass yield, and proximate and fatty acid compositions in meat. However, birds fed diets containing various components of candlenut had small effect on reducing feed intake, decreasing crude protein and crude fat contents in meat, and increasing total C18:2n-6 and n-6 PUFA. In conclusion, supplementation of various components of candlenut kernel in broiler diet did not improve growth performance, carcass yield, and proximate and fatty acid compositions in meat.
\end{abstract}

Keywords: Aleurites moluccana; fatty acid; broiler; candlenut kernel; broiler carcass

\section{INTRODUCTION}

The use of antibiotics as a growth promoter in livestock feed has been banned in many countries since 2006 due to its harmful residues in animal products. This action started in Europe where Sweden was the first country to ban the use of antibiotic growth promoter (AGPs), followed by other countries. In July 2011, the Republic of Korea also banned the use of these AGPs (Lee et al., 2017). Although the use of AGPs started since the 1950s, it was banned due to the universal human security factor. Instead, researchers have sought various alternatives to address this issue. The use of natural growth promoter comprising plant resources such as herbs and spices, fat dietary source such as linseed meal, flaxseed meal, chia meal, and rapeseed oil, has been shown to have a beneficial effect in which they do not only improve the digestion of nutrients, but also increase gut morphology, immune system, fatty acid profile of meat, growth, and feed efficiency of animal (Hashemi et al., 2014; Al-Khalifa et al., 2012; Mridula et al., 2011, Carillo et al., 2008) and the products are also safe for human consumption.

Candlenut or its scientific name Aleurites moluccana is a common spice that contains high levels of fatty acids. It is also known as Buah Keras in Malaysia, Kemiri in Indonesia, Indian Walnut in India, and Kukui in Hawaii. A. moluccana kernels are commonly used for cuisine, beauty cosmetic, and skin care. Since it comes from Euphorbieceae family, it contains phorbol, saponin (Rohaida et al., 2014), and phytotoxin (Covacevich et al., 1987). However, the amounts of these components depend on the type of variety as some varieties have been shown to be non toxic (Walter \& Sam, 2002), safe for internal uses due to the lack of toxicity, and its extract also has the potential to treat selected Autoimmune Inflammatory Diseases by inhibiting the growth of the bacterial triggers (Mpala et al., 2017). The kernel contains more than $60 \%$ extracted oil, and some researchers note that it can react in a living cell (Martin et al., 2010). The most special characteristic of this seed is that it is known to contain high proportions of polyunsaturated fatty acid (PUFA) such as Omega-3, Omega-6, and Omega-9 which between the ranges of $28.1 \%$ to $29.5 \%, 38.1 \%$ to $41.6 \%$, and $21.6 \%$ to $22.6 \%$, respectively (Martin et al., 2010; Rohaida et al., 2014).

Supplementing either treated or untreated candlenut meal at $2 \%$ level was shown to enhance the fatty acid profiles in broiler chickens meat (Rohaida et al., 2014). The hypothesis was that various components of candlenut kernel would affect the performance and carcass characteristics of broiler chicken, especially candlenut kernel defatted due to less saponin content. This present study was therefore conducted to deter- 
mine the effects of components of raw candlenut kernel supplementation in the diet on growth performance, carcass yield, and proximate and fatty acid composition in the meat of broiler chickens.

\section{MATERIALS AND METHODS}

\section{Preparation of Raw Kernel and Chemical Analysis}

Ten kilograms of raw candlenut kernel was purchased from a local market and stored in a cool and dry place. A mortar and pestle were used to grind the kernel to obtain particles of 2-3 $\mathrm{mm}$ diameter. The ground candlenut kernel was separated into three components; (1) candlenut kernel, (2) candlenut kernel oil, and (3) defatted candlenut kernel. A coconut oil press machine from Jabatan Pertanian Ulu Dusun, Sandakan was used to extract the oil from the kernels.

The nutrient contents in candlenut kernel, diets, and meat such as moisture, dry matter, ash, crude protein, crude fiber, crude fat, and nitrogen-free extract were analyzed according to the methods described by Association of Official Analytical Chemists (AOAC, 1984) method, while anti-nutrient content, saponin, was determined using the method adopted by Nwosu et al. (2010). The gross energy contents of the samples were determined using a Fully Automatic Bomb Calorimeter C2000, Adiabatic, IKA®, from Germany. Composition of fatty acids in the samples was also determined using Gas Chromatography (Ebrahimi et al., 2014). Each sample was performed using at least three replicates.

\section{Experimental Animal and Dietary Treatment}

A total of 100 day-old male broiler chicks, Cobb500, were bought from a local commercial hatchery and were allocated randomly in floor pens, measuring $0.6 \mathrm{~m}$ length, $0.5 \mathrm{~m}$ width, and $0.3 \mathrm{~m}$ high in an open house type. Upon arrival, the chicks were wing-banded, individually weighed, and recorded before being placed in the brooding. Anti-stress preparation was given through drinking water for 3 consecutive days started on the $1^{\text {st }}$ day of chicks arrival. IB and ND vaccinations were carried out on the $7^{\text {th }}$ and $14^{\text {th }}$ days via eye drop. Drinking water and feed were given ad libitum. From day 1 to day 21, the chicks were fed broiler commercial starter diet containing 21\% crude protein (CP) and $2900 \mathrm{kcal} /$ $\mathrm{kg}$ metabolism energy (ME). On day 21, all birds were individually weighed and divided equally into four dietary treatment groups (Table 1) namely; T1, basal diet containing no candlenut kernel (Control); T2, basal diet supplemented with $2.5 \%$ whole candlenut kernel meal (CK); T3, basal diet supplemented with $2.5 \%$ candlenut kernel oil (CKO); and T4, basal diet supplemented with 2.5\% candlenut kernel defatted (CKD). The experiment was conducted in a completely randomized design (CRD) where each treatment group had 5 replicates, and each replicate had 5 birds. Beginning from day 21 to day 42 , birds were fed according to their respective dietary treatment groups. All diets were formulated in isonitrogenous to meet the nutrient requirement of chickens
(NRC, 1994) for Cobb ration. The diets were given to the birds in mash form.

\section{Variables and Sampling}

Body weight, body weight gain, feed intake, feed conversion ratio, and mortality rate were measured to determine their growth performances. Body weight and feed intake were measured weekly, body weight gain and feed conversion ratio were calculated based on body weight and feed intake data. At the end of the experiment, one bird from each replicate was selected randomly, slaughtered according to the method of halal procedure, scalded, de-feathered, and eviscerated (internal organ were removed). The dressed weight (head, feather, leg, and internal organs were removed), liver, kidney, abdominal fat pad (from the proventriculus surrounding the gizzard), and gizzard were obtained and recorded. They were expressed as a percentage of live weight (Tohid et al., 2008; Tang et al., 2011; Leke et al., 2018). Whole breast, thigh drumstick, and wings yield were manually cut and weighed and were expressed of carcass weight (Freitas et al., 2018: Reyes et al., 2018). Fifty gram of the left breast and thigh meat was taken, placed in a seal clear plastic sample, and immediately stored at $-20^{\circ} \mathrm{C}$ prior to proximate and fatty acid analysis.

\section{Experimental Design and Statistical Analysis}

All the data except mortality were analyzed using One Way ANOVA according to the general linear model (GLM) procedure of SAS9.4 (SAS2009). Significant differences among treatments means were determined at $\mathrm{p}<0.05$ by Duncan's Multiple Range Test (DMRT). Mortality was determined by Chi-Square Test.

\section{RESULTS}

The growth performances of broiler chickens fed with various components of candlenut kernel are presented in Table 2. Supplementation of $2.5 \%$ various components in broiler diets did not improve growth performance of body weight, body weight gain, feed conversion ratio (FCR), and mortality rate, except feed intake. The lowest feed intake (116.8 g) was observed in T2 (CK) compared to control and other treatments.

Table 3 shows the dressing percentage, various cuts, and organs of the broiler carcass. There was no significant difference in the cuts and organs weights of birds fed various dietary treatments.

There was no significant difference observed among the proximate compositions of broiler meat, except for the crude protein and fat contents (Table 4). The highest crude protein and crude fat were found in birds on treatment T2 which were $23.15 \%$ and $36.61 \%$, respectively.

Table 5 shows the fatty acid composition (\% of fatty acid) of breast muscle. There was no significant difference was observed among the dietary treatment groups, unless for C18:2n-6 and n-6 PUFA. Supplementation of $2.5 \%$ various components of candlenut kernel in the diet 
increased the omega-6 (C103.8:2n-6) and n-6 PUFA compared to control group (T1). The highest C18:2n-6 and n-6 PUFA were found in T3 (CKO) which were $21.98 \%$ and $25.40 \%$, respectively. However, there was no significant impact was observed on fatty acid composition (\% of total fatty acid) of thigh muscle (Table 6).

\section{DISCUSSION}

Modification of broiler diets by including various components of ground candlenut kernel improved the fatty acid profiles in the diet. Differences fatty acids contribute in varying amounts to the composition of different tissues (Kanakri et al., 2017).

In the present study, supplementation of various components of ground candlenut kernel at $2.5 \%$ in the diets increases the crude fat up to $12.95 \%$, and saponin content also increased $(0.85 \%)$ in the diet which was higher in CK compared to the other treatments. As the crude fat in the diets increased, the saponin content also increased. Even though the crude fat and saponin contents of the diet did not show a significant $(\mathrm{p}<0.05)$ difference, it might slightly affect the feed intake. The result of feed intake obtained in this study also concluded that the feed intake was inversely related to energy concentration in the diet. This result might be due to the caloric requirement of the birds (as much as $12.5 \%$ crude fat in T2) was fulfilled and thus they ate less. Previous findings also noted that fulfillment of caloric requirement causes less feed intake (Abbas et al., 2016). However, less feed intake might be due to the higher saponin content in T2 $(0.85 \%)$. Saponin has been claimed to reduce feed intake and inhibit the growth rate of poultry, and show toxicological effects with the

Table 1. Composition of experimental broiler grower-finisher diet

\begin{tabular}{|c|c|c|c|c|}
\hline & \multicolumn{4}{|c|}{ Dietary treatments } \\
\hline & T1 (Control) & $\mathrm{T} 2(\mathrm{CK})$ & $\mathrm{T} 3(\mathrm{CKO})$ & $\mathrm{T} 4$ (CKD) \\
\hline \multicolumn{5}{|l|}{ Ingredients (\%) } \\
\hline Ground yellow corn & 60.00 & 60.00 & 60.00 & 60.00 \\
\hline Soybean meal dehulled & 25.00 & 25.00 & 25.00 & 25.00 \\
\hline Fish meal & 7.00 & 7.00 & 7.00 & 7.00 \\
\hline Crude palm oil & 5.40 & 2.90 & 2.90 & 2.90 \\
\hline Limestone & 1.30 & 1.30 & 1.30 & 1.30 \\
\hline Fine salt & 0.25 & 0.25 & 0.25 & 0.25 \\
\hline Mineral premix ${ }^{1}$ & 0.25 & 0.25 & 0.25 & 0.25 \\
\hline Vitamin premix ${ }^{2}$ & 0.25 & 0.25 & 0.25 & 0.25 \\
\hline Lysine 99\% & 0.20 & 0.20 & 0.20 & 0.20 \\
\hline DL-Methionine 98\% & 0.15 & 0.15 & 0.15 & 0.15 \\
\hline Mono dicalcium phosphate (MDCP) & 0.10 & 0.10 & 0.10 & 0.10 \\
\hline Choline chloride & 0.10 & 0.10 & 0.10 & 0.10 \\
\hline Candlenut & 0.00 & 2.50 & 2.50 & 2.50 \\
\hline \multicolumn{5}{|l|}{ Laboratory analysis: } \\
\hline Dry matter (\%) & $86.88 \pm 0.80$ & $88.33 \pm 0.25$ & $88.74 \pm 0.03$ & $88.20 \pm 0.01$ \\
\hline Ash (\%) & $7.53 \pm 0.20$ & $5.62 \pm 0.20$ & $5.43 \pm 0.09$ & $5.59 \pm 0.29$ \\
\hline Crude protein (\%) & $20.5 \pm 0.12$ & $20.7 \pm 0.29$ & $20.2 \pm 0.10$ & $20.9 \pm 0.45$ \\
\hline Crude fiber $(\%)$ & $6.35 \pm 0.25$ & $6.50 \pm 0.40$ & $6.90 \pm 0.50$ & $6.60 \pm 0.30$ \\
\hline Crude fat $(\%)$ & $5.34 \pm 0.40$ & $12.95 \pm 0.27$ & $9.68 \pm 0.21$ & $8.55 \pm 0.30$ \\
\hline Gross energy (MJ/ kg) & $16.68 \pm 0.39$ & $16.86 \pm 1.09$ & $17.53 \pm 0.79$ & $17.97 \pm 0.67$ \\
\hline Saponin $(\%)$ & $0.165 \pm 0.02^{\mathrm{c}}$ & $0.848 \pm 0.03^{\mathrm{a}}$ & $0.548 \pm 0.16^{\mathrm{ab}}$ & $0.383 \pm 0.07 \mathrm{c}$ \\
\hline C18:1n-9 & $31.55 \pm 0.53^{\mathrm{a}}$ & $29.51 \pm 0.00^{\mathrm{b}}$ & $31.12 \pm 0.67^{\text {ba }}$ & $29.40 \pm 0.11^{\mathrm{b}}$ \\
\hline$C 18: 2 n-6$ & $32.79 \pm 0.18^{c}$ & $40.03 \pm 0.00^{\mathrm{a}}$ & $35.85 \pm 1.02^{\mathrm{b}}$ & $40.25 \pm 0.05^{\mathrm{a}}$ \\
\hline$C 18: 3 n-3$ & $3.62 \pm 1.95$ & $4.34 \pm 0.00$ & $4.06 \pm 0.56$ & $2.70 \pm 0.10$ \\
\hline Saturated fatty acid (SFA) & $31.66 \pm 1.52^{\mathrm{a}}$ & $25.54 \pm 0.00^{\mathrm{b}}$ & $27.87 \pm 1.87^{\text {ba }}$ & $27.11 \pm 0.03^{\text {ba }}$ \\
\hline Monounaturated fatty acid (MUFA) & $31.91 \pm 0.61^{\mathrm{a}}$ & $30.09 \pm 0.00^{\mathrm{b}}$ & $32.20 \pm 0.30^{\mathrm{a}}$ & $29.93 \pm 0.19^{b}$ \\
\hline n-6 PUFA & $32.79 \pm 0.18^{c}$ & $40.03 \pm 0.00^{\mathrm{a}}$ & $35.85 \pm 1.02^{\mathrm{b}}$ & $40.25 \pm 0.05^{\mathrm{a}}$ \\
\hline n-3 PUFA & $3.62 \pm 1.95$ & $4.34 \pm 0.00$ & $4.06 \pm 0.56$ & $2.70 \pm 0.10$ \\
\hline$n-6 / n-3$ & $12.67 \pm 6.75$ & $9.22 \pm 0.00$ & $8.95 \pm 0.99$ & $14.94 \pm 0.55$ \\
\hline
\end{tabular}

Note:

Means in the same row with different superscripts differ significantly; All data are on dry matter basis; $n-6$ PUFA= omega- 6 polyunaturated fatty acid; n-3 PUFA= omega-3 polyunaturated fatty acid; n-6/n-3= ratio omega- 6 and omega-3; T1= basal diet containing no candlenut kernel (Control); $2=$ basal diet supplemented with $2.5 \%$ whole candlenut kernel meal (CK); T3= basal diet supplemented with $2.5 \%$ candlenut kernel oil (CKO); T4= basal diet supplemented with $2.5 \%$ candlenut kernel defatted (CKD)

${ }^{1}$ Mineral premix (per kg): selenium 0.2 g; iron 80 g; manganese 100 g; zinc 80 g; copper 15 g; potassium chloride 4 g; magnesium oxide 0.6 g; sodium bicarbonate $1.5 \mathrm{~g}$; iodine $1 \mathrm{~g}$; cobalt $0.25 \mathrm{~g}$.

${ }^{2}$ Vitamin premix (per kg): vitamin A 50IU; vitamin D 10 IU; vitamin E 75 g; vitamin K3 20 g; vitamin B1 10 g; vitamin B2 30 g; vitamin B12 0.1 g; D-calcium pantothenate $60 \mathrm{~g}$; nicotinic acid $200 \mathrm{~g}$; folic acid $5 \mathrm{~g}$; biotin $235 \mathrm{~g}$. 
Table 2. Growth performance of broiler chickens fed various components of ground candlenut kernel on day 42 of age (Mean \pm SE)

\begin{tabular}{lcccc}
\hline \multirow{2}{*}{ Variables } & \multicolumn{4}{c}{ Dietary treatments } \\
\cline { 2 - 5 } & $\mathrm{T} 1$ (Control) & $\mathrm{T} 2(\mathrm{CK})$ & $\mathrm{T} 3(\mathrm{CKO})$ & $\mathrm{T} 4(\mathrm{CKD})$ \\
\hline Initial body weight $(\mathrm{g} / \mathrm{bird})$ & $869.0 \pm 3.78$ & $864.9 \pm 1.44$ & $865.6 \pm 2.64$ & $867.2 \pm 2.71$ \\
Final body weight $(\mathrm{g} / \mathrm{b}$ ird) & $2141.8 \pm 53.79$ & $2162.4 \pm 19.88$ & $2226.5 \pm 16.01$ & $2216.6 \pm 22.28$ \\
Average daily gain $(\mathrm{g} / \mathrm{bird})$ & $60.6 \pm 2.56$ & $61.8 \pm 0.99$ & $64.8 \pm 0.67$ & $64.3 \pm 1.03$ \\
Feed intake $(\mathrm{g} / \mathrm{bird} /$ day) & $121.1 \pm 1.38^{\mathrm{a}}$ & $116.8 \pm 1.17^{\mathrm{b}}$ & $122.6 \pm 1.25^{\mathrm{a}}$ & $123.7 \pm 0.98^{\mathrm{a}}$ \\
Feed conversion ratio & $2.21 \pm 0.168$ & $1.94 \pm 0.030$ & $1.94 \pm 0.023$ & $2.01 \pm 0.037$ \\
Mortality $(\%)$ & 0 & 0 & 0 & 0 \\
\hline
\end{tabular}

Note: *Means in the same row with different superscripts differ significantly $(\mathrm{p}<0.05)$; All data are on dry matter basis; $\mathrm{T} 1=\mathrm{basal}$ diet containing no candlenut kernel (Control); T2= basal diet supplemented with 2.5\% whole candlenut kernel meal (CK); T3= basal diet supplemented with $2.5 \%$ candlenut kernel oil (CKO); T4= basal diet supplemented with 2.5\% candlenut kernel defatted (CKD).

Table 3. Carcass yield of broiler chickens fed various components of A. moluccana kernel on day 42 of age (Mean \pm SE)

\begin{tabular}{lcccc}
\hline \multirow{2}{*}{ Variables } & \multicolumn{4}{c}{ Dietary treatments } \\
\cline { 2 - 4 } & T1 (Control) & T2 (CK) & T3 (CKO) & T4 (CKD) \\
\hline Carcass weight (g) & $1374 \pm 61.81$ & $1467 \pm 87.70$ & $1419 \pm 75.95$ & $1419 \pm 97.86$ \\
Dressing \% & $65.0 \pm 1.82$ & $63.3 \pm 1.19$ & $64.2 \pm 0.94$ & $66.7 \pm 0.67$ \\
Liver (\%) & $1.81 \pm 0.198$ & $1.70 \pm 0.095$ & $1.78 \pm 0.075$ & $1.95 \pm 0.247$ \\
Abdominal fat pad (\%) & $1.91 \pm 0.143$ & $1.84 \pm 0.427$ & $1.73 \pm 0.228$ & $1.22 \pm 0.053$ \\
Gizzard (\%) & $1.55 \pm 0.114$ & $1.60 \pm 0.078$ & $1.59 \pm 0.070$ & $1.68 \pm 0.097$ \\
Breast (\%) & $22.69 \pm 1.0$ & $22.93 \pm 1.2$ & $22.42 \pm 0.7$ & $21.54 \pm 1.6$ \\
Thigh (\%) & $27.81 \pm 6.3$ & $28.39 \pm 7.6$ & $29.96 \pm 8.1$ & $28.16 \pm 11.1$ \\
Wing (\%) & $11.24 \pm 0.4$ & $11.15 \pm 0.4$ & $11.53 \pm 0.5$ & $11.70 \pm 0.6$ \\
\hline
\end{tabular}

Note: All data are on dry matter basis; $\mathrm{T} 1=$ basal diet containing no candlenut kernel (Control); $\mathrm{T} 2=$ basal diet supplemented with $2.5 \%$ whole candlenut kernel meal (CK); T3= basal diet supplemented with $2.5 \%$ candlenut kernel oil (CKO); T4= basal diet supplemented with $2.5 \%$ candlenut kernel defatted (CKD).

Table 4. Proximate composition in broiler meat (Mean \pm SE)

\begin{tabular}{lcccc}
\hline \multirow{2}{*}{ Components (\%) } & \multicolumn{4}{c}{ Dietary treatments } \\
\cline { 2 - 5 } & T1 (Control) & T2 (CK) & T3 (CKO) & T4 (CKD) \\
\hline Dry matter & $26.78 \pm 0.12$ & $27.24 \pm 0.42$ & $27.01 \pm 0.09$ & $27.36 \pm 0.29$ \\
Moisture & $73.42 \pm 0.09$ & $72.76 \pm 0.42$ & $72.99 \pm 0.09$ & $72.64 \pm 0.29$ \\
Ash & $1.94 \pm 0.03$ & $1.93 \pm 0.06$ & $1.80 \pm 0.07$ & $1.80 \pm 0.16$ \\
Crude protein & $22.93 \pm 0.24^{\mathrm{a}}$ & $21.48 \pm 0.32^{\mathrm{b}}$ & $23.15 \pm 0.27^{\mathrm{a}}$ & $21.48 \pm 0.26^{\mathrm{b}}$ \\
Ether extract & $31.02 \pm 0.41^{\mathrm{b}}$ & $28.47 \pm 0.69^{\mathrm{c}}$ & $36.61 \pm 0.47^{\mathrm{a}}$ & $15.09 \pm 0.65^{\mathrm{d}}$ \\
\hline
\end{tabular}

Note: *Means in the same row with different superscripts differ significantly $(\mathrm{p}<0.05)$; All data are on dry matter basis; $\mathrm{T} 1=$ basal diet containing no candlenut kernel (Control); T2= basal diet supplemented with $2.5 \%$ whole candlenut kernel meal (CK); T3= basal diet supplemented with $2.5 \%$ candlenut kernel oil (CKO); T4= basal diet supplemented with 2.5\% candlenut kernel defatted (CKD).

Table 5. Fatty acid composition (\% of total fatty acid) of breast muscle (Mean \pm SE)

\begin{tabular}{|c|c|c|c|c|}
\hline \multirow{2}{*}{ Fatty acids } & \multicolumn{4}{|c|}{ Dietary treatments } \\
\hline & T1 (Control) & $\mathrm{T} 2(\mathrm{CK})$ & $\mathrm{T} 3(\mathrm{CKO})$ & $\mathrm{T} 4$ (CKD) \\
\hline C18:1n-9 & $38.48 \pm 0.77$ & $34.90 \pm 1.02$ & $32.64 \pm 0.53$ & $32.78 \pm 4.22$ \\
\hline$C 18: 2 n-6$ & $15.96 \pm 0.89^{b}$ & $16.61 \pm 0.92^{b}$ & $21.98 \pm 0.23^{a}$ & $17.57 \pm 0.53^{\mathrm{b}}$ \\
\hline$C 18: 3 n-3$ & $4.46 \pm 1.61$ & $3.78 \pm 0.50$ & $4.29 \pm 0.25$ & $2.59 \pm 0.36$ \\
\hline SFA & $35.85 \pm 0.95$ & $37.74 \pm 1.02$ & $33.64 \pm 0.28$ & $37.47 \pm 2.56$ \\
\hline MUFA & $41.30 \pm 1.25$ & $38.69 \pm 0.29$ & $35.88 \pm 0.08$ & $36.48 \pm 6.04$ \\
\hline n-6 PUFA & $18.04 \pm 0.68^{b}$ & $19.23 \pm 1.16^{\mathrm{ba}}$ & $25.40 \pm 0.56^{\mathrm{a}}$ & $22.43 \pm 2.76^{\text {ba }}$ \\
\hline n-3 PUFA & $4.80 \pm 1.52$ & $4.33 \pm 0.43$ & $5.0 \pm 0.20$ & $3.61 \pm 0.72$ \\
\hline$n-6 / n-3$ & $4.12 \pm 1.16$ & $4.51 \pm 0.72$ & $5.03 \pm 0.31$ & $6.31 \pm 0.49$ \\
\hline
\end{tabular}

Note: Means in the same row with different superscripts differ significantly $(\mathrm{p}<0.05)$. All data are on dry matter basis; $\mathrm{T} 1=$ basal diet containing no candlenut kernel (Control); T2= basal diet supplemented with $2.5 \%$ whole candlenut kernel meal (CK); T3= basal diet supplemented with $2.5 \%$ candlenut kernel oil (CKO); T4= basal diet supplemented with 2.5\% candlenut kernel defatted (CKD); SFA= Saturated Fatty Acid; MUFA= Monounsaturated Fatty Acid; n-6 PUFA= Omega-6 Polyunsaturated Fatty Acid; n-3 PUFA= Omega-3 Polyunsaturated Fatty Acid; n-6/n-3= Ratio Omega-6 and Omega-3. 
Table 6. Fatty acid composition (\% of total fatty acid) of thigh muscle (Mean \pm SE)

\begin{tabular}{|c|c|c|c|c|}
\hline \multirow{2}{*}{ Fatty acids } & \multicolumn{4}{|c|}{ Dietary treatments } \\
\hline & T1 (Control) & $\mathrm{T} 2(\mathrm{CK})$ & $\mathrm{T} 3(\mathrm{CKO})$ & $\mathrm{T} 4$ (CKD) \\
\hline C18:1n-9 & $31.18 \pm 3.35$ & $34.63 \pm 0.69$ & $30.51 \pm 4.02$ & $30.38 \pm 0.67$ \\
\hline C18:2n-6 & $16.12 \pm 2.05$ & $18.19 \pm 1.04$ & $20.09 \pm 0.96$ & $19.31 \pm 1.12$ \\
\hline C18:3n-3 & $6.96 \pm 4.17$ & $3.38 \pm 0.33$ & $4.37 \pm 0.04$ & $2.9 \pm 0.28$ \\
\hline SFA & $37.50 \pm 0.46$ & $35.62 \pm 0.29$ & $36.17 \pm 3.58$ & $36.40 \pm 0.18$ \\
\hline MUFA & $34.16 \pm 3.59$ & $39.29 \pm 1.64$ & $33.08 \pm 5.12$ & $35.23 \pm 2.73$ \\
\hline n-6 PUFA & $20.58 \pm 1.45$ & $21.15 \pm 1.54$ & $25.48 \pm 1.15$ & $24.68 \pm 2.20$ \\
\hline n-3 PUFA & $7.72 \pm 4.57$ & $3.93 \pm 0.19$ & $5.26 \pm 0.38$ & $3.66 \pm 0.35$ \\
\hline$n-6 / n-3$ & $4.28 \pm 2.72$ & $5.41 \pm 0.65$ & $4.84 \pm 0.13$ & $6.74 \pm 0.04$ \\
\hline
\end{tabular}

Note: All data are on dry matter basis; T1= basal diet containing no candlenut kernel (Control); T2= basal diet supplemented with $2.5 \%$ whole candlenut kernel meal (CK); T3= basal diet supplemented with $2.5 \%$ candlenut kernel oil (CKO); T4= basal diet supplemented with $2.5 \%$ candlenut kernel defatted (CKD); SFA= Saturated Fatty Acid; MUFA= Monounsaturated Fatty Acid; n-6 PUFA= Omega-6 Polyunsaturated Fatty Acid; n-3 PUFA= Omega-3 Polyunsaturated Fatty Acid; n-6/n-3= Ratio Omega-6 and Omega-3.

level in diets. In contrast, the other researchers noted that saponin was used as a feed additive to promote a better growth rate and feed efficiency, lower serum cholesterol level, reducing the emission of ammonia from animals' excreta, assist the absorption of nutrient, and improve carcass quality. Thigh meat seemed higher than breast meat. A similar result was reported by Leke et al. (2018) that thigh meat $(237.80 \mathrm{~g})$ was higher than breast meat $(216.60 \mathrm{~g})$ when he conducted an experiment to determine the use of fish oil as a by-product of a fish canning factory in diet on the performance and lipid profiles of native chicken. This result could be due to the different fatty acid contents in various components of candlenut had different effects that contributed more to thigh than to breast meat yield. The percentages of wings and abdominal fat pad obtained in this study are within the range (Faria et al., 2010). Furthermore, many experiments showed no significant difference in broiler's growth performance parameters when different fat sources were fed (Poorghasemi et al., 2013).

Saturated fatty acids component such as palmitoleic acid could reduce bad cholesterol, as well as fat deposition in blood vessels and blood clot formation, while unsaturated fatty acid could improve the flavor of meat and health benefits. In the present study, the increased level of crude fat and saponin contents in the diet (CK) may lead to decreased feed intake. It also produced lower dressing weight and wings weight. These results indicate that as the level of crude fat in the diet increase, the contents of saponin in the diet will increase. The increase in saponin content of the diet will reduce the amount of feed intake that normally will decrease the percentage of carcass yield. The supplementation of sheanut cake containing saponin at a rate of more than $25 \mathrm{~g} / \mathrm{kg}$ in the broiler diet also reduces carcass yield. However, in the present study, no significant ( $p>0.05)$ difference was observed within the dietary treatments. Poorghasemi et al. (2013) also demonstrated that dietary fat source did not alter the weight of internal organs and small intestinal.

Fat-based feedbacks such as soyabean oil, rapeseed oil, and other processed fat products did not affect the chemical composition of chicken meat. Bostami et al. (2017) also reported that the chemical composition of broiler meat was not affected by different dietary fat sources, unless for crude fat in breast meat. Candlenut kernel oil in T3 group had the highest content of fat $(36.61 \%)$ than control (31.02\%). This condition could be related to the higher contribution of unsaturated fatty acid (USFA) to the diet.

The total of n-6 PUFA in T3 (CKO) was automatically higher than those in control and other treatment groups. Higher n-6 PUFA content could be due to the higher C18:2n-6 component in T3. Incorporation of polyunsaturated fatty acid (PUFA) component in the breast was higher than in the thigh. Koreleski \& Swiatkiewicz (2007) demonstrated that the inclusion of different levels of fatty acids in a diet plays an important role in the increased some of the fatty acid components in breast and thigh muscles. The sources of dietary fat could affect the lipid content depending on the type of muscle (del Puetro et al., 2017) (i.e. the lipid content was lower in pectoralis muscle than in Gastrocnemius muscle in broiler supplemented with inorganic and organic selenium). The breast was demonstrated to contain higher PUFA than thigh (Trembekka et al., 2016). In opposite, the concentrations of total lipids and fatty acids were significantly higher in thigh and leg than in breast muscle (Morales-Barrera et al., 2013).

\section{CONCLUSION}

Supplementing $2.5 \%$ of various components of candlenut kernel in the diet did not improve growth performance, carcass yield, the chemical composition of broiler meat, and fatty acid composition of breast and thigh muscles of finishing broiler chickens.

\section{CONFLICT OF INTEREST}

We certify that there is no conflict of interest with any financial, personal, or other relationships with other people or organization related to the material discussed in the manuscript.

\section{ACKNOWLEDGEMENT}

This research was supported by the Research and Innovation Management Centre, Universiti 
Malaysia Sabah under the research grant number, SLB-0118-STWN-2016.

\section{REFERENCES}

Abbas, M. T., M. Arif, M. Saeed, M. Reyad-ul-Ferdous, M. A. Hassan, M. A. Arain, \& A. Rehman. 2016. Emulsifier effect on fat utilization in broiler chicken. Asian J. Anim. Vet. Adv. 11:158-167. https://doi.org/10.3923/ajava.2016.158.167

AOAC. 1984. Official Methods of Analysis. Association of Official Analytical Chemists. 14th ed. Assoc. Off. Anal. Chem., Arlington.

Al-Khalifa, H., D. I. Givens, C. Rymer, \& P. Yaqoob. 2012. Effect of n-3 fatty acids on immune function in broiler chickens. Poult. Sci. 91:74-88. https://doi.org/10.3382/ps.2011-01693

Bostami, A. B. M. R., H. S. Mun, \& C-J. Yang. 2017. Breast and thigh meat chemical composition in fatty acid profile in broilers fed diet with dietary fat sources. J. Food Process Technol. 8: 672. https://doi.org/10.4172/2157-7110.1000672

Carrillo, S., F. Lopez, M. M. Casas, E. Avila, R. M. Castillo, M. E. Carronco, C. Calco, \& F. Perez-Gil. 2008. Potential use of seaweeds in the laying hen ration to improve the quality of n-3 fatty acid enriched eggs. J. Appl. Phycology. 20:271278. https://doi.org/10.1007/s10811-008-9334-4

Covacevich, J., P. Davie, \& J. Pearn. 1987. Toxic Plants and Animals: A Guide for Australia. Queensland Museum, Brisbane. Pp. 369-389.

del Puerto, M., M. C. Cabrera, \& S. Ali. 2017. A note on fatty acids profile of meat from broiler chickens supplemented with inorganic or organic selenium. Int. J. Food Sci. Vol. 2017, Article ID 7613069. https://doi.org/10.1155/2017/7613069

Ebrahimi, M., M. A. Rajion, \& Y. M. Goh. 2014. Effects of oils rich in linoleic and $\alpha$-linolenic acids on fatty acid profile and gene expression in goat meat. Nutrients. 6:3913-3928. https://doi.org/10.3390/nu6093913

Faria, P. B., M. C. Bressan, X. R. D. Souza, L. V. Rossato, L. M. G. Botego, \& L. T. D. Gama. 2010. Carcass and part yield of broilers reared under a semi-extensive system. Brazilian J. Poult. Sci. 12: 153-159. https://doi.org/10.1590/ S1516-635X2010000300003

Freitas, H. B. D., K. M. R. D. S. Nascimento, C. Kiefer, G. A. Gomes, T. T. D. Santos, E. R. M. Garcia, T. R. D. Silva, L. L. Paiva, \& P. R. Berno. 2019. Graded levels of phytase on performance, bone mineralization and carcass traits of broiler fed reduced dicalcium phosphate. AsianAustralas. J. Anim. Sci. 32: 691-700. https://doi.org/10.5713/ ajas. 18.0228

Hashemi, S. M., T. C. Loh, H. L. Foo, I. Zulkifli, \& M HairBejo. 2014. Dietary putrescine effects on performance parameters, nutrient digestibility, intestinal morphology and tissue polyamine content of broilers fed low protein diet. Iran. J. Vet. Res. 15:385-391

Kanakri, K., J. Carragher, R. Hughes, B. Muhlhausler, \& R. Gibson. 2018. The effect of different dietary fats on the fatty acid composition of several tissues in broiler chickens. Eur. J. Lipid Sci. Technol. 120:1-13. https://doi.org/10.1002/ ejlt.201700237

Koreleski, J. \& S. Swiatkiewicz. 2007. Dietary supplementation with plant extracts, xantophylls and synthetic antioxidants: Effect of fatty acid profile and oxidative stability of frozen stored chicken breast meat. J. Anim. Feed Sci. 16:463-471.

Leke, J. R., J. S. Mandey, J. T. Laihad, R. M. Tinangon, L. Tangkau, \& C. Junus. 2018. Performance and lipid profiles of native chickens fed diet containing skipjack fish oil as by-product of fish canning factory. IOP Conf. Ser.: Earth Environ. Sci. 102 012041. https://doi. org/10.1088/1755-1315/102/1/012041
Lee, J. Y., G. G. Han, H-B. Lee, S-M. Lee, S-K. Kang, G-D. Jin, J. Park, B. J. Chae, Y. H. Choi, E. B. Kim, \& Y-J. Choi. 2017. Prohibition of antibiotic growth promoters has affected the genomics profiles of Lactobacillus salivarius inhabiting the swine intestine. PLOS ONE 12:e0186671. https://doi. org/10.1371/journal.pone.0186671

Martin, C., A. Moure, G. Martin, E. Carrillo, H. Dominquez, \& J. C. Parajo. 2010. Fractional characterization of jatropha, neem, moringa, trisperma, castor and candlenut seeds as potential feedstock for biodiesel production in Cuba. Biosmass and Bioenergy 34:553-538. https://doi. org/10.1016/j.biombioe.2009.12.019

Morales-Barrera, J. E., M. J. Gonzalez-Alcorta, R. M. CastilloDominguez , O. F. Prado-Rebolledo, X. HernandezVelasco, A. Menconi, G. Tellez, B. M. Hargis, \& S. Carrillo-Dominguez. 2013. Fatty acid deposition on broiler meat in chickens supplemented with tuna oil. Food Nutr. Sci. 4:16-20. https://doi.org/10.4236/fns.2013.49A1003

Mpala, L. N., G. R. Chikowe, \& I. E. Cock. 2017. Aleurites moluccanus (1.) Willd. extracts inhibit the growth of bacterial triggers of selected autoimmune inflammatory diseases. Pharmacogn. Commn. 7:83-90. https://doi.org/10.5530/ pc.2017.2.12

Mridula, D., D. Kaur, S. S. Nagra, P. Barnwal, S. Gurumayum, \& K. K. Singh. 2012. Effect of dietary flaxseed supplementation on egg production and quality in laying hens. Indian J. Poult. Sci. 40:40-47.

NRC (National Research Council). 1994. Nutrient Requirement of Poultry. 9th rev. ed. National Academy Press, Washington, DC.

Nwosu, J. N., C. N. Ubbaonu, E. O. I. Banigo, \& A. Uzomah 2010. The effects of processing on the anti-nutritional properties of 'oze' (Bosquiea angolensis) seeds. New York Sci J. 3:106-111.

Poorghasemi, M., A. Seidavi, A. A. A. Qotbi, V. Laudadio, \& V. Tufarelli. 2013. Influence of dietary fat source on growth performance responses and carcass traits of broiler chicks. Asian-Australas. J. Anim. Sci. 26:705-710. https://doi. org/10.5713/ajas.2012.12633

Reyes, F. C. C., A. T. A. Aguirre, E. M. Agbisit Jr, F. E. Merca, G. L. Manulat, \& A. A. Angeles. 2018. Growth performances and carcass characteristics of broiler chickens fed akasya [Samanea Saman (Jacq.) Merr.] pod meal. Tropical Anim. Sci. 41: 46-52. https://doi.org/10.5398/tasj.2018.41.1.46

Rohaida, A. R., A. R. Alimon, \& A. Q. Sazili. 2014. Fatty acid composition of breast and thigh muscles of broiler fed diets supplemented with candlenut kernel meal subjected to different heat treatments. Malaysian J. Anim. Sci. 17:47-60.

Tang, S. C., I. Zulkifli, M. Ebrahimi, A. R. Alimon, A. F. Soleimani, \& K. Filer. 2011. Effects of feeding different levels of corn dried distillers grains with soluble on growth performance, carcass yield and meat fatty acid composition in broiler chickens. Int. J. Anim. Vet. Advances. 3:205-211.

Tohid, V., N-A. Kambiz, E-N. Yahya, M-S. Naser, \& V. Sina. 2008. The effects of energy increasing and protein lowering by addition on fats to diet on broiler chickens: Performance and Serum Lipids. Asian J. Anim. Advances. 3: 286-292. https://doi.org/10.3923/ajava.2008.286.292

Trembecka, L., P. Hascik, J. Cubon, M. Bobko \& A. Pavelkova. 2016. Fatty acids profile of breast and thigh muscles of broiler chickens fed diets with propolis and probiotics. J. Central European Agri. 17: 1179-1193. https://doi. org/10.5513/JCEA01/17.4.1828

Walter, A. \& C. Sam. 2002. Fruits of Oceania. ACIAR Monograph 85. Australian Center for Agricultural Research. Canberra, Australia.

Woods, V. B. \& A. M. Fearon. 2009. Dietary sources of unsaturated fatty acids for animals and their transfer into meat, milk and eggs: A review. Livestock Sci. 126:1-20. https:// doi.org/10.1016/j.livsci.2009.07.002 